the whole continental shelf round Britain and is considering a powered submersible for underwater geology. The Navy undoubtedly leads in actual experience, and its new programme should stimulate progress elsewhere. The emphasis on practical operations rather than depth records is encouraging. Diving ships and equipment are very expensive and it would be sensible if some sharing of national facilities and know-how could be achieved. An effective mechanism for collaboration does not yet exist. For two years there has been a continuing dialogue between the Navy, industrial representatives, the Ministry of Technology and the Ministry of Defence, but nothing very much has come of it-and the Department of Education and Science, the government department responsible for NERC, has not been involved.

\section{Aerodynamics at NPL}

THIs week the National Physical Laboratory at Teddington has been holding its open days and it is particularly pleased with the work it does in the engineering sciences. The laboratory has an industrial aerodynamics section concentrating on the effects of air or water flow on structures. It was the industrial aerodynamics section, for instance, which tested the design of the suspension bridges over the Forth and the Severn, and the Post Office towers in London and Birmingham. For work of this kind, the section has six wind tunnels for testing various kinds of model which for many purposes have to represent not only the appearance of the actual structure but its elastic and dynamic behaviour as well.

Recently, the section has worked on the design of what is to be the tallest chimney in Britain, an 850 feet stack for the power station at Drax in Yorkshire. Tall chimneys, it seems, tend to oscillate in the wind, but at right-angles to the wind direction. The oscillations are damped by fitting some kind of sleeve around the top of the chimney; the exact shape of the sleeve has to be determined by wind tunnel tests. The suspension bridge is another structure well known to be susceptible to wind induced oscillations, not only when the bridge is completed but also during construction, when its dynamic properties may differ appreciably from those of the finished structure. Present practice is to test the behaviour not only of the final bridge but also of the various stages in its construction, as was done for the Severn bridge by the aerodynamics section at the National Physical Laboratory.

One of the demonstrations in the wind tunnels at the NPL is a model of the Wye extension to the Severn bridge. As the Wye extension is a comparatively simple structure, it was not felt necessary to test the design in a wind tunnel before construction. The finished bridge in fact has now been found to oscillate to some extent in the wind. This has been seized upon by the aerodynamics section as an opportunity for evaluating their testing procedures. Only structures which show sufficiently small oscillations in wind tunnel tests are ever built, and consequently aerodynamicists are not certain how close are the more severe oscillations measured in model tests to the oscillations which would occur in real structures. The section is now testing the model of the Wye extensions, and says that the oscillations could in fact have been predicted accurately before construction.

\section{Parliament in Britain}

$$
\text { by our Parliamentary Correspondent }
$$

Irish Sea

THE Minister of Power, Mr Ray Gunter, announced that another area of the continental shelf beneath the Irish Sea had been designated undar Section $1(7)$ of the Continental Shelf Act. This was so that he could be kept informed of the progress of investigations by holders of exploration licences. The Natural Environment Research Council was drilling a test borehole and undertaking a seismic survey, which would show whether the Irish Sea merited further exploration. (Written answer, June 14.)

\section{Metrication}

Mr Robert MeLlish, Minister of Public Building and Works, was more explicit on the subject of metrication than other members of the Government have so far been. From January 1 next year, most new projects entering the design stage would be carried out in the metric system, and $\mathrm{Mr}$ Mellish said that he had appointed a senior professional officer as metrication officer. His ministry was issuing a series of booklets intended to help designers in the changeover, and he had set up a working party within the ministry to look into aspects of the change not directly the concern of the British Standards Institution. Mr Mellish said that he would ensure that a Metrication Board would be set up as quickly as possible, in consultation with the Minister of Technology. (Oral answer, June 17.)

\section{Multi-story Buildings}

Mr ANTHony Greenwood, Minister of Housing and Local Government, reported that approval had been given for the construction in England and Wales of some twenty-nine dwellings built by the system of construction which had been used in the collapsed block of flats at Canning Town in London. He said that he hoped to have the report into the Canning Town collapse as soon as possible, but was unwilling to do anything which might prejudge the findings of the tribunal. (Oral answer, June 18.)

\section{Non-proliferation}

Mr Fred MUlley, Minister of State at the Foreign Office, made a statement about the non-proliferation treaty. The General Assembly of the United Nations, he said, had by an overwhelming majority approved a resolution commending the draft treaty. The Government believed the treaty to be the most important and substantial measure of disarmament and arms control that had yet been achieved, and that it was the first step in achieving the end of the nuclear arms race. The United States, the USSR and Britain had put forward security assurances, which envisaged immediate Security Council action in the event of a nuclear threat or nuclear aggression against a nonnuclear country. The countries not supporting the treaty were Albania, Cuba, Tanzania and Zambia. Twenty-one countries, including France, had abstained. (Statement, June 19.)

\section{German Measles}

MR EDWARD SHORT said that the recent survey by the Medical Research Council into the effectiveness of measles vaccine had not included consideration of German measles, an unrelated illness. The council was therefore organizing a separate series of trials for German measles vaccines. (Oral answer, June 20.) 